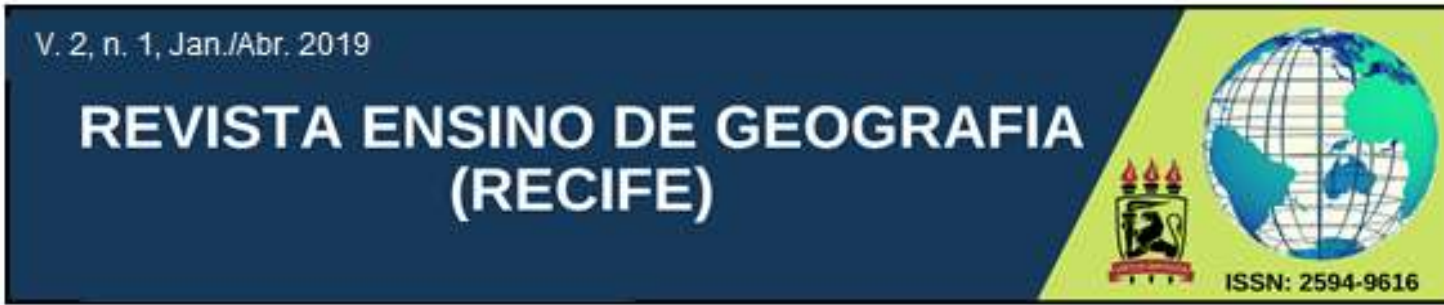

\title{
ESPAÇOS NÃO-FORMAIS NO ENSINO DE GEOGRAFIA: A IMPORTÂNCIA DO OBSERVATÓRIO ASTRONÔMICO ANTARES EM FEIRA DE SANTANA/BA
}

\author{
Jonathas Jesus dos Santos \\ Mestre em Modelagem em Ciências da Terra e do Ambiente pela (UEFS) \\ jonathasjsantoss@gmail.com \\ ORCID Id: https://orcid.org/0000-0003-4558-7602
}

\section{Artigo recebido em 18/12/2018 e aceito em 11/03/2019}

\begin{abstract}
RESUMO: O ensino de Geografia, nos espaços não-formais, permite uma saída alternativa das quatro paredes da sala de aula, favorecendo ao estudante contato direto com outras possibilidades de construção do conhecimento. Nesse sentido, o objetivo geral deste trabalho visa compreender como os espaços nãoformais de ensino são utilizados pelos professores no/para o ensino da Geografia escolar. Logo, utilizouse uma abordagem qualitativa para a investigação, com o estudo de caso do Observatório Astronômico Antares em Feira de Santana-Ba. Os instrumentos para a coleta de dados, foram observações, questionários e entrevistas com os professores de Geografia da educação básica. Elaborou-se duas categorias temáticas: A primeira delas, relata a importância dos espaços não-formais de ensino: do discurso à prática, relatando as contradições entre as falas e as práticas dos professores de Geografia, a outra, sobre a utilização dos espaços não-formais no ensino de Geografia. Constatou-se que grande parte dos professores ainda estão presos ao ambiente escolar, desconhecendo na maioria das vezes as potencialidades de um espaço não-formal de ensino. Entretanto, muitos professores de Geografia utilizam os espaços não-formais, tanto institucionalizados quanto não-institucionalizados, para aulas expositivas e dialogadas, colaborando com a aprendizagem significativa e trazendo ainda mais sentido para o mundo em volta dos alunos.
\end{abstract}

Palavras-Chave: Ensino-Aprendizagem; Espaços não-formais; Recursos didáticos.

\section{NON-FORMAL SPACES IN GEOGRAPHY EDUCATION: THE IMPORTANCE OF OBSERVATÓRIO ASTRONÔMICO ANTARES IN FEIRA DE SANTANA /BA}

\begin{abstract}
The teaching of Geography, in non-formal spaces, allows an exit from the four walls of the classroom, favoring the desire to be at a distance with other possibilities of knowledge construction. In this sense, the general objective is how non-formal educational spaces are defended by secondary school teachers. Therefore, we used a qualitative approach for an investigation, with the case study of the Antares Astronomical Observatory in Feira de Santana-Ba. The instruments for data collection were viewed, questionnaires and interviews with teachers of Geography of basic education. Two thematic categories were elaborated: The first one, the relevance of the non-formal spaces of teaching: the discourse to the practice, reporting as contradictions the speeches and the practices of the teachers of Geography, another one, on the use of the spaces nonforms in the Geography teaching. It was found that a large number of teachers are still available in the school environment, and sometimes the possibilities of a non-formal teaching space. However, many Geography teachers use the unformed spaces, although they
\end{abstract}


are little informed about the non-institutionalized, for expository and dialogic classes, collaborating with meaningful learning and making even more sense for the students' world.

Keywords: Teaching-Learning; Non-formal spaces; Didactic resources;

\section{INTRODUÇÃO}

Os espaços não-formais de ensino podem contribuir com os professores de Geografia que, muitas vezes, estão presos a uma rotina em sala de aula. Isso acontece devido à falta de estrutura e precariedade da unidade escolar, com ausência de equipamentos e materiais que possam suprir as necessidades da prática docente. Nessa perspectiva, o ensino de Geografia, nos espaços não-formais, permite uma saída alternativa das quatro paredes da sala de aula, favorecendo ao estudante o contato direto com outras possibilidades de ensino.

Neste local, a reconstrução do mundo a partir da representação poderia tornar o ensino de Geografia mais facilmente compreensível. Logo, os espaços não-formais desempenham um papel fundamental que pode colaborar com o ensino escolar, uma vez que contêm outras possibilidades de construção do conhecimento por meio da representação, ou o contato direto com aquilo que está sendo estudado.

Observa-se que a educação pode ser dividida em três diferentes formas: a primeira seria a educação formal, a segunda a informal e a terceira a educação nãoformal. "A educação formal é aquela desenvolvida nas escolas, com conteúdos previamente demarcados, a informal como aquela que os indivíduos aprendem durante seu processo de socialização [...], e a educação não-formal é aquela que se aprende "no mundo da vida", via os processos de compartilhamento de experiências, principalmente em espaços e ações coletivas" (GOHN, 2006, p. 28), sendo este último o foco desse trabalho.

Para embasar a discussão dessa pesquisa, toma-se por base autores como (JACOBUCCI, 2008, p. 64), que destaca que "os espaços não-formais de ensino podem aproximar a sociedade do conhecimento científico”. (PINTO \& FIGUEIREDO, 2010, p.1) aborda que "o currículo escolar não deve ser apenas proposto e realizado dentro do espaço escolar”. (PAZ et al., 2011, p.184) reforça a ideia destacando que essas ações "podem contribuir na capacitação de profissionais da educação a olhar para outras formas de atingir o "ser social", bem como a possibilitar o desenvolvimento de metodologias diferenciadas de integrar arte e educação". 
Para a realização da investigação, optou-se pela pesquisa qualitativa, do tipo estudo de caso. O lócus foi o Observatório Astronômico Antares - OAA de Feira de Santana - BA. Nesse sentido, foi levantada a seguinte questão: "como a escola utiliza os espaços não-formais (Observatório Astronômico Antares) no ensino de Geografia escolar?"

O objetivo geral da pesquisa foi compreender como os espaços não-formais de ensino são utilizados pelos professores no/para o ensino da Geografia escolar. Como objetivos específicos pretendeu-se identificar se os professores de Geografia utilizam espaços não-formais no ensino de Geografia; Analisar como os professores utilizam as atividades desenvolvidas no OAA para construção do conhecimento da Geografia escolar; Analisar como os professores de Geografia articulam as atividades desenvolvidas no OAA e as atividades subsequentes na sala de aula; e identificar a importância atribuída ao Observatório Astronômico Antares.

\section{METODOLOGIA}

Esta pesquisa é caracterizada como qualitativa que "é definida como aquela que privilegia a análise de microprocessos, através do estudo das ações sociais individuais e grupais, realizando um exame intensivo dos dados" (MARTINS, 2004, p.289). Dentro da abordagem qualitativa, foi trabalhado com o estudo de caso do espaço não-formal de ensino Observatório Astronômico Antares. Nesse sentido, pretendeu-se analisar qualitativamente as contribuições que os espaços não-formais têm para o ensino de Geografia e para a vivência dos estudantes.

O Observatório Astronômico Antares - OAA (Figura 1 a 3), foi fundado na década de 1970 por Augusto Cesar e no ano de em 1992 se tonou parte da Universidade Estadual de Feira de Santana - UEFS. Ao longo dos anos, outros setores da UEFS foram agregados ao OAA ampliando suas atividades. Na contemporaneidade, o OAA conta com um núcleo de Sensoriamento Remoto com o desenvolvimento de mapas e monitoramento de áreas, uma biblioteca setorial interligada ao sistema de bibliotecas da UEFS, um planetário equipado com um moderno projetor, além de uma estrutura para a investigação astronômica. Ademais, o observatório possui um museu que pode potencializar o ensino de Geografia: o Museu Antares de Ciência e Tecnologia (MACT). 
O MACT conta com um espaço natureza com exposições de animais taxidermizados dos diferentes biomas da Bahia, espaço sobre preservação e conscientização dos recursos naturais, outro espaço sobre o big bang, tabela periódica, rochas e minerais, réplicas de meteoritos e de foguetes, o parque dos dinossauros com réplicas em tamanho natural dos antigos dinossauros que viveram no Brasil, parque dos mamíferos com réplicas de animais da era do gelo, Stonehenge, a conquista espacial, caminhada lunar e relógio solar. Basicamente o MACT tenta contar a história da formação do planeta Terra desde o big bang, até os dias atuais. Além disso, o museu conta com um espaço dedicado a construção do conhecimento de Física e Química com equipamentos práticos para a demonstração de vários fundamentos físicos e químicos.

OBSERVATÓRIO ASTRONÔMICO ANTARES EM FEIRA DE SANTANA-BA
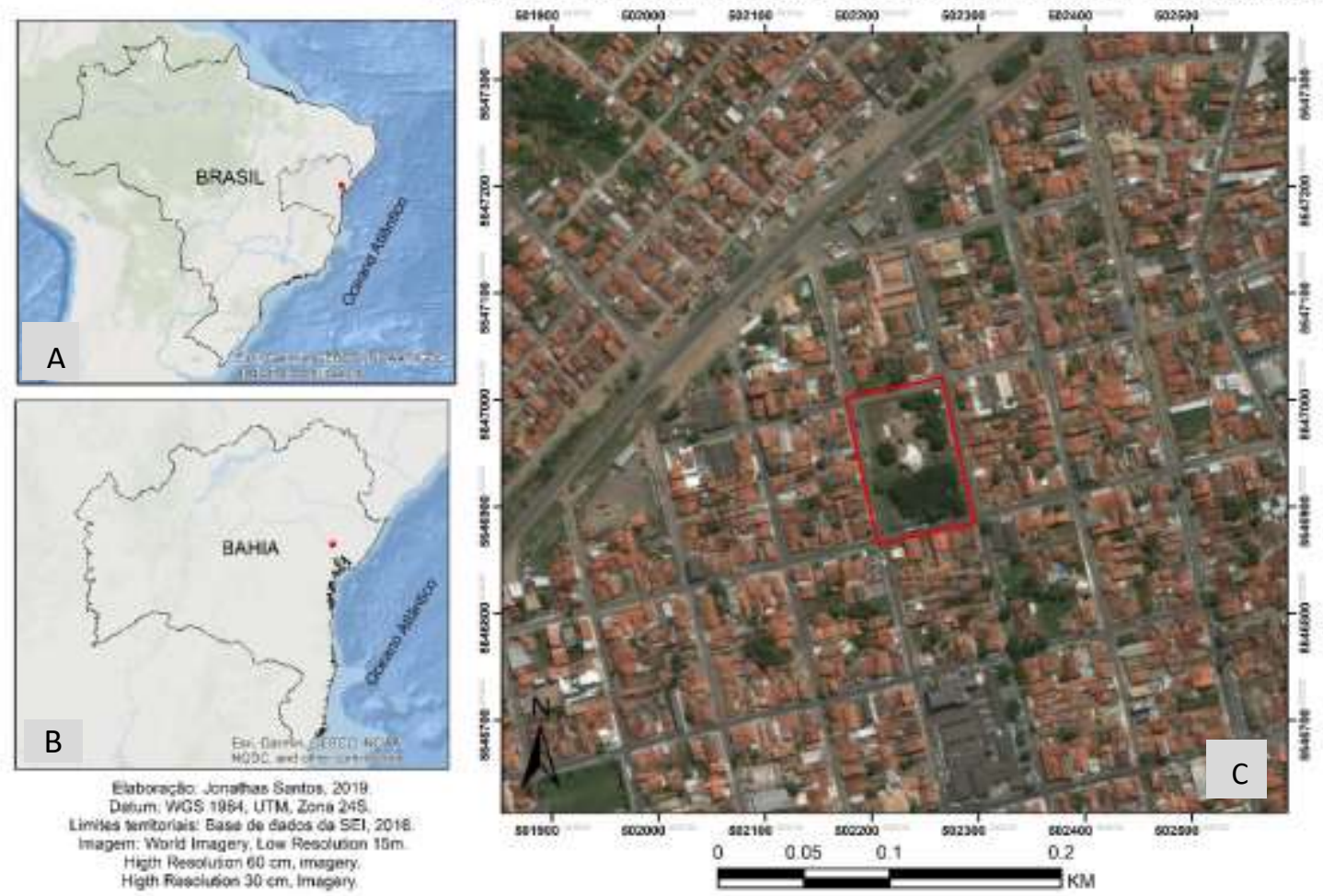

Figura 1 - (A) Localização do estado da Bahia no Brasil. Observa-se um pequeno ponto vermelho dentro do limite territorial da Bahia, representando a localização do Observatório Astronômico Antares. (B) Localização do Observatório Astronômico Antares no Estado da Bahia. (C) Localização do observatório Astronômico Antares na cidade de Feira de Santana-Ba, o limite territorial está delimitado em vermelho.

As atividades desenvolvidas no OAA são voltadas principalmente para escola básica, mas o OAA também desenvolve outras atividades de extensão para a comunidade, bem como para o ensino superior e técnico. Nesse sentido, existe uma 
grande procura pelos professores da educação básica pelas palestras do OAA, principalmente os professores de Geografia da cidade de Feira de Santana-BA e cidades circunvizinhas. Na maioria das vezes, os professores de Geografia desconhecem as potencialidades existentes no observatório para a construção do ensino, e acabam se impressionando com as inúmeras possibilidades existentes no OAA para se trabalhar no ensino de Geografia.

Os instrumentos utilizados para a coleta de dados, foram questionários e entrevistas com os professores de Geografia da educação básica. Assim, levantou-se questionamentos para compreender como os professores utilizam os espaços nãoformais e quais as contribuições para o ensino de Geografia. Foram aplicados questionários com oito professores de Geografia da escola básica, bem como realizada entrevistas com três professores de Geografia no Observatório Antares e na escola Básica.

Também foram observadas as palestras ministradas no Observatório Astronômico Antares para escolas do ensino fundamental e médio, analisando qualitativamente como são as atividades desenvolvidas por este espaço não-formal de ensino e suas contribuições para o ensino de Geografia. Os dados encontrados foram agrupados em duas categorias temáticas: importância dos espaços não-formais de ensino: do discurso à prática; e a utilização de espaços não-formais no ensino de Geografia.

\section{QUADRO TEÓRICO DE REFERÊNCIA}

Sobre os espaços não-formais de ensino (JACOBUCCI, 2008, p. 56), destaca que "duas categorias podem ser sugeridas: locais que são Instituições e locais que não são Instituições. Como exemplo de instituições existem Museus, Centro de Ciências, Parques ecológicos, Observatórios, Zoológicos, entre outros", que contam com uma equipe responsável pelas atividades desenvolvidas. Já não instituições existem “teatro, parque, casa, rua, praça, terreno, cinema, praia, caverna, rio, lagoa, campo de futebol, dentre outros inúmeros espaços". Assim, percebe-se a variedade de espaços não-formais de ensino, tanto institucionalizados, quanto não-institucionalizados que podem potencializar a construção do ensino de Geografia. 


\begin{abstract}
Alguns espaços não-formais de educação têm se constituído como campo para diversas pesquisas em educação que buscam compreender principalmente as relações entre os espaços não-formais e a Educação formal no Brasil. Museus de arte têm sido estudados pela recente divulgação cultural, em parceria com escolas, zoológicos, dentre outros, como locais favoráveis à realização de projetos de Educação Ambiental, e os museus e centros de ciências têm recebido grande atenção dos pesquisadores pela potencialidade de envolvimento da comunidade escolar com a cultura científica. (JACOBUCCI, 2008, p. 3)
\end{abstract}

Nessa perspectiva, verifica-se a importância que vem sendo dada aos espaços não-formais de ensino pelas pesquisas em educação, visto que podem colaborar com a educação formal. Logo, "o currículo escolar não deve ser apenas proposto e realizado dentro do espaço escolar, mas elaborado também com intuído de abranger locais onde os alunos possam ter uma reflexão mais ampla do conhecimento do ensino de Ciências" (PINTO \& FIGUEIREDO, 2010, p.1). Os espaços não-formais "podem contribuir na capacitação de profissionais da educação a olhar para outras formas de atingir o "ser social", bem como a possibilitar o desenvolvimento de metodologias diferenciadas de integrar arte e educação" (PAZ et al., 2011, p.184). Sendo assim:

Todo e qualquer espaço pode ser utilizado para uma prática educativa de grande significação para professores e estudantes. Contudo, antes da prática é necessário construir um planejamento criterioso para atender ambos os objetivos - professores e estudantes. No planejamento, deve-se ter atenção, principalmente, com a segurança dos estudantes neste ambiente, para evitar imprevistos e também saber quais os recursos ali existentes que poderão ser utilizados durante a prática de campo com os estudantes. (QUEIROZ, 2011 p. 7)

Nesse sentido, o ensino escolar não deve se restringir apenas as salas de aula, visto que qualquer espaço não-formal de ensino pode contribuir com o processo de ensino e aprendizagem. Entretanto, assim como é realizado um planejamento para uma aula nas escolas, também deve ser feito um planejamento para a visita em um espaço não-formal de ensino.

\begin{abstract}
A ideia de estudar Geografia nos espaços não-formais é trazer para seu aprendizado uma experiência de vida, uma vivência estimulante para melhor reflexão acerca da relevância que elementos ou atores sociais podem nos proporcionar mediante o ensino de Geografia nos espaços não-formais, pois através destes lugares diferentes que o estudante passa a conhecer outras formas de relações sociais. (SANTANA \& JÚNIOR 2014, p.2).
\end{abstract}

Logo, nos espaços não-formais "é possível desmistificar a complexidade das ciências, proporcionando metodologias inovadoras que estimulam a capacidade criativa e crítica dos indivíduos envolvidos" (ROMANZINI \& BATISTA, 2009, p. 9). Ainda se 
observa que "representar é mobilizar os saberes prévios de cada sujeito para que a realidade objetivada seja interpretada e administrada, e assim possamos juntos (re)construir um mundo melhor em uma consciência planetária" (CASTROGIOVANNI \& SOLER, 2010, P. 1). Portanto, torna-se mais fácil a compressão de um determinado assunto, utilizando a representação, além de potencializar a fuga do ensino tradicional de Geografia. Sendo que:

\begin{abstract}
Na pedagogia tradicional, o homem é visto como um receptor passivo que, ao adquirir certas informações, pode repeti-la a outros que ainda não as possuem. Nessa perspectiva, a educação é entendida como instrução, caracterizada pela transmissão de conhecimentos realizada exclusivamente por intermédio da ação da escola. Nesse modelo, a presença do professor, detentor de todo o conhecimento, é indispensável e as avaliações são exatamente a reprodução dos conteúdos comunicados em sala de aula. (NASCIMENTO et al., 2014, p.2130)
\end{abstract}

Nesse contexto, constata-se ainda na atualidade práticas pedagógicas tradicionais, em que o aluno é apenas receptor e o professor transmissor de conhecimentos. Prende-se os estudantes somente as salas de aula e não se busca alternativas diferenciadas de ensino. Se reproduzem as mesmas aulas cotidianamente, uma inalterabilidade que provoca aversão e desestímulo nos educandos. Entretanto,

É importante ressaltar que, embora seja de senso comum que a Educação não-formal é diferente da Educação formal, por utilizar ferramentas didáticas diversificadas e atrativas, isto nem sempre é verdade. Há muitos exemplos de professores que adotam estratégias pedagógicas variadas para abordar um determinado conteúdo, fugindo do tradicional método da aula expositiva não dialogada. E também há exemplos de aulas estritamente tradicionais e autoritárias sendo realizadas em espaços não-escolares. (JACOBUCCI, 2008, p. 2).

Verifica-se que práticas tradicionais podem existir em qualquer lugar, independentemente do espaço ser formal ou não-formal. Entretanto, o espaço nãoformal não perde sua validade, bem como assim não perde sua validade os espaços considerados formais. Caberá ao professor de Geografia transformar uma aula vista como tradicional em construtiva em sala de aula. Também é importante ressaltar que dificilmente se encontrará um espaço não-formal baseado na pedagogia tradicional, já que estes espaços trabalham com exposições e diálogos.

“A utilização dos espaços não formais de educação contribui para a construção contextualizada dos conhecimentos à medida que o aluno tem a oportunidade de investigar e problematizar situações" (NASCIMENTO et al., 2014, p. 2130). Logo, 
verifica-se que é de grande importância o trabalho fora dos muros da escola, uma vez que os estudantes são levados a analisar o mundo em que vivem, trazendo sentido a realidade.

\section{RESULTADOS DA PESQUISA}

Com as análises dos dados das entrevistas, questionários e observações, foi possível elaborar duas categorias temáticas. A primeira delas, relata a importância dos espaços não-formais de ensino: do discurso à prática, relatando as contradições entre as falas e as práticas dos professores de Geografia, a outra, sobre a utilização dos espaços não-formais no ensino de Geografia. Relatou-se como os espaços não-formais de ensino são utilizados pelos professores no/para o ensino da Geografia escolar.

\subsection{A IMPORTÂNCIA DOS ESPAÇOS NÃO-FORMAIS DE ENSINO: DO DISCURSO À PRÁTICA}

Constatou-se através dos questionários e entrevistas que todos os professores de Geografia dizem considerar importantes os espaços não-formais para o ensino de Geografia. Muitos afirmaram, inclusive, que o ensino não se restringe as salas de aula e a escola, mas sim ao contexto de vivência do indivíduo. Outros afirmaram que esses espaços podem potencializar que o aluno contextualize e problematize situações do seu cotidiano que não são percebidas, na maioria das vezes, em sala de aula.

De acordo com um professor de Geografia entrevistado no OAA “esses espaços são de fundamental importância no ensino da Geografia escolar, pois contribuem para uma aprendizagem significativa, ou seja, provocam o estudante a atribuir significado ao estudo do espaço geográfico no qual ele está inserido. Como alguns destes espaços estão mais próximos da sua residência ou bairro, espera-se que eles motivem ainda mais o estudante e o faça perceber a relação da Geografia escolar com a sua vida". Uma outra professora de Geografia também entrevistada no OAA relatou que "Acredita que a utilização dos espaços não-formais de educação pode contribuir para a construção contextualizada de conhecimentos à medida que permite ao aluno oportunidades de investigar e problematizar situações do seu cotidiano".

Em contrapartida, são poucos professores que relataram utilizar algum espaço não-formal de ensino. Segundo um professor de Geografia entrevistado na escola básica 
"é bastante interessante um espaço não-formal de ensino, mas nunca utilizei esses espaços para as aulas (por diversos entraves logísticos e financeiros), foge da rotina". Logo é perceptível que "a normativa social institui que o processo de aprendizagem só existe dentro de um determinado espaço para educação de indivíduos" (SANTANA \& JÚNIOR, 2014, p. 1). Observa-se que a sociedade de modo geral, enxerga uma concepção de formação e conhecimento procedente somente da educação formal, existe um desconhecimento muito grande dos espaços não-formais e suas potencialidades para o ensino.

Cerca de $90 \%$ dos professores relataram nos questionários que as escolas em que trabalham não contam com nenhum tipo de laboratório para o ensino de Geografia, nem mesmo laboratório de informática. Na maioria das vezes, os professores de Geografia têm carência de materiais didáticos para o ensino, como mapas, globo terrestre, jogos, entre outros. Logo é visível a falta de alternativa e de estrutura dentro da escola para o trabalho com o ensino de Geografia.

"O espaço não formal pode, mediante a sua estrutura física, fornecer recursos didáticos para o aprendizado que a escola não possui” (PINTO \& FIGUEIREDO, 2010, p.3) Dessa forma, constata-se, principalmente em escolas públicas, a carência de materiais e recursos para o trabalho com as aulas de Geografia. Desse modo, reforça-se ainda mais a importância dos espaços não-formais de ensino, que na contramão dos fatos, possuem esses recursos para a construção do conhecimento.

O espaço formal combinado ao espaço não-formal, pode suprir carências de ensino e ter como resultado uma a aprendizagem significativa, tornando o ensino de Geografia mais facilmente compreensível, com aulas expositivas e dialogadas. Logo, leva-se o estudante além da sala de aula e dos muros da escola, na tentativa de mostrar a realidade presente no mundo, realidade essa que tantas vezes os professores tentam mostrar dentro da sala de aula e sem o êxito desejado, pois os alunos na maioria das vezes não associam o que está sendo falado com a realidade.

\subsection{A UTILIZAÇÃO DE ESPAÇOS NÃO-FORMAIS NO ENSINO DE GEOGRAFIA}

Apenas $40 \%$ dos professores relataram que já utilizaram museus, parques e praças para construção do ensino de Geografia. Nesse contexto, necessitaram anteriormente, construir um planejamento criterioso para que a atividade no espaço não- 
formal de ensino obtivesse êxito. Um dos professores de Geografia relatou que realizou um planejamento para visitar algumas ruas e praças da cidade, pretendeu observar questões sobre reciclagem e preservação ambiental. Nesse cenário, solicitou aos estudantes uma pesquisa sobre os temas que seriam abordados e realizou uma discussão em sala de aula. Posteriormente, realizou juntamente com os estudantes uma caminhada por algumas ruas e praças próximas da escola discutindo a questão ambiental.

De acordo com o professor "os alunos perceberam que os espaços em que os mesmos estavam inseridos precisavam de atenção e cuidados, sendo que aqueles mesmos lugares que passaram, acabavam descrevendo um pouco da história de cada um”. Uma outra professora de Geografia da escola básica relatou que já levou os seus estudantes para um centro de ciências. Nesse cenário, segundo ela, foi necessário realizar anteriormente uma visita juntamente com outros professores ao espaço para realizar um planejamento pedagógico. Após a visita e construção do planejamento, os estudantes foram levados ao centro de ciências para assistirem projeções. Ao retornar para a sala de aula a professora aplicou um questionário avaliativo com questionamentos sobre a projeção que o aluno tinha assistido no centro de ciências.

Cerca de $70 \%$ dos professores de Geografia relataram que em seu planejamento pedagógico dificilmente ou nunca contemplam atividades para serem desenvolvidas em espaços não-formais para o ensino. Isso porque segundo eles, seria muito difícil o trabalho fora da escola, existe um desconhecimento sobre os espaços, ou até mesmo existe um comportamento inadequado dos estudantes e falta de recursos financeiros para o trabalho de campo, principalmente em escolas públicas.

Os professores do ensino formal "dificilmente têm como medir os impactos dos conhecimentos que podem ser gerados em um espaço não-formal, entre vários motivos, geralmente está o fato de poucos terem trabalhado ou realizado extensão em algum espaço não-formal” (CASTROGIOVANNI \& SOLER, 2010, p.1). Nessas circunstâncias, observa-se que parte dos professores de Geografia podem acabar desconhecendo as contribuições e potencialidades de um espaço não-formal justamente por não o conhecer.

Não é comum se pensar em outras alternativas e nem mesmo tenta-se vencer os obstáculos para que seja realizada uma visita a um espaço não-formal, utilizando-se apenas do espaço formal para o ensino. Visualiza-se apenas os espaços não-formais institucionalizados, mas não se pensa nos espaços não-formais não-institucionalizados 
como ruas, praças, lagoas, entre outros que podem significativamente colaborar com o ensino.

$\mathrm{Na}$ maioria das vezes, até mesmo algumas ruas próximas da escola podem colaborar com vários assuntos de Geografia, como as dinâmicas urbanas e sociais, relação entre o homem e a natureza, questões ambientais, serviços públicos urbanos, relevo, solo, hidrografia, vegetação, entre outros. Aulas nesses espaços podem levar o estudante a perceber a Geografia presente cotidianamente, e a transformar uma abstração em realidade.

Em uma das entrevistas, uma professora de Geografia da educação básica que estava trabalhando com cartografia em sala de aula, relatou que não imaginava que o Observatório Astronômico Antares (OAA), poderia contribuir com o ensino de cartografia e até mesmo climatologia, uma vez que se trabalhava no planetário com constelações, orientação geográfica, além das palestras no Stonehenge e no relógio solar sobre os conceitos de latitude, longitude, solstícios, equinócios, estações do ano e precessão da Terra (Figura 2 e 3).

Um outro professor de Geografia relatou que era um local ideal para trabalhar com o tempo geológico, rochas e minerais, uma vez que o OAA contava com um local sobre a origem do universo e big bang, o parque dos dinossauros, parque dos mamíferos, além de uma outra parte dedicada a falar sobre rochas e minerais (Figura 2 e $3)$.

Os professores de Geografia relataram nas entrevistas e questionários que as atividades que desenvolvem com os estudantes logo depois da visita ao OAA são relatórios, questionários, portfólios e uma tentativa de associação do que foi visto com o assunto que está sendo trabalhado em sala de aula.

Logo, “dependendo da percepção do aluno, ele pode analisar informações relevantes em um espaço não formal de ensino, onde, na escola, um determinado tema abordado relacionado a esse espaço informal, não foi adequadamente informado" (PINTO \& FIGUEIREDO, 2010, p. 3) Nesse sentido, a professora de Geografia que estava trabalhando com cartografia, relatou que depois da palestra seria muito mais fácil o trabalho com a cartografia em sala de aula, pois os estudantes associariam o que foi visto como o relógio solar, planetário e a Stonehenge com o conteúdo trabalhado. 


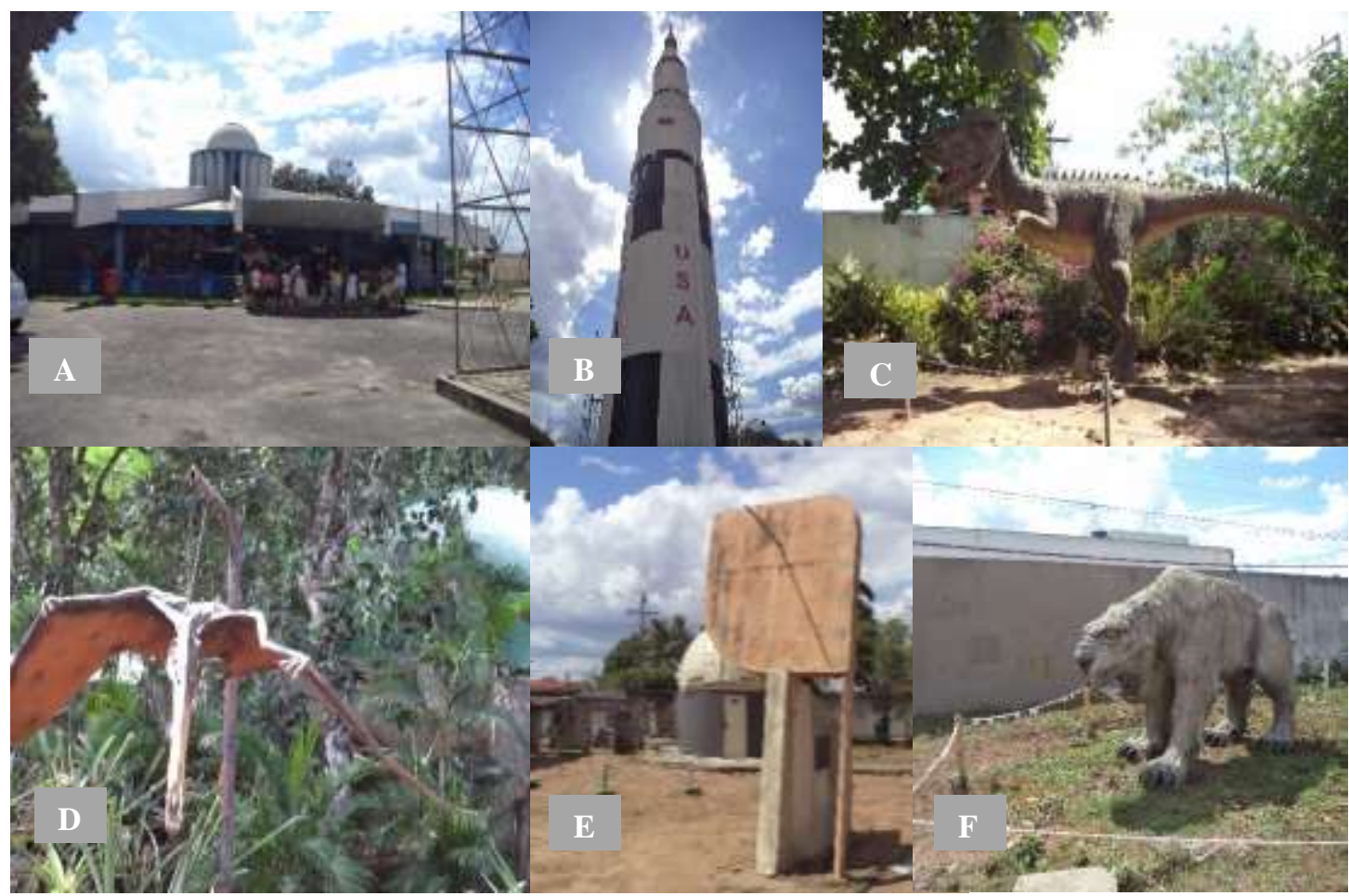

Figura 2. Mosaico de imagens do Observatório Astronômico Antares. (A) Área central do Observatório; (B) Réplica do foguete espacial Saturno V; (C) Réplica de dinossauro brasileiro; (D) Réplica de um Pterossauro brasileiro; (E) Relógio Solar; (F) Réplica do Tigre Dente-de-Sabre; Fonte das imagens: Jonathas Santos (2016).
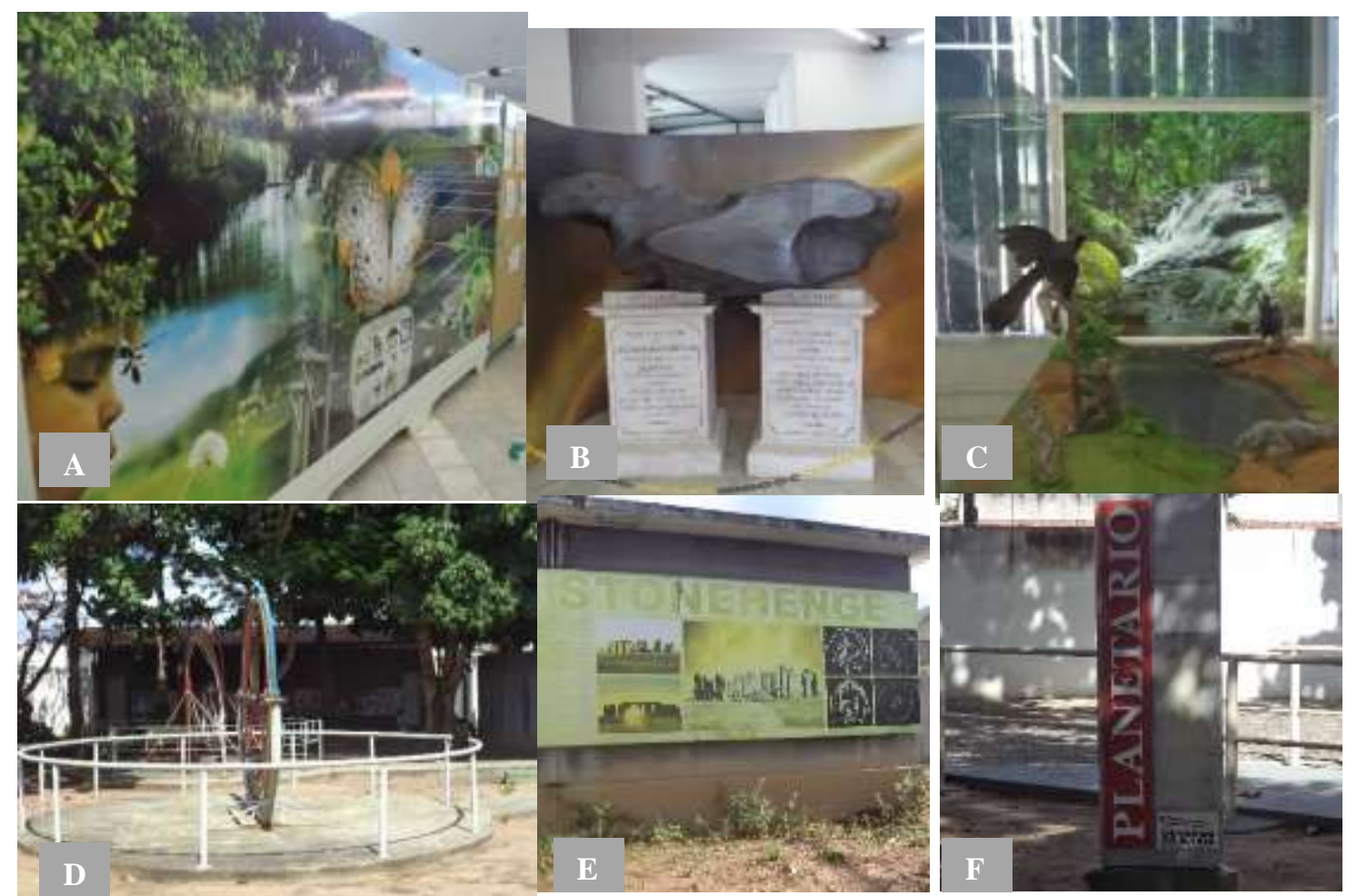

Figura 3. Mosaico de imagens do Observatório Astronômico Antares. (A) Espaço de conscientização Ambiental; (B) Réplica do lendário meteorito de Bendegó; (C) Espaço Natureza, animais do bioma Mata Atlântica (D) Aparelho de simulação de zero gravidade Girotec; (E) Descrições da Stonehenge; (F) Entrada do Planetário. Fonte das imagens: Jonathas Santos (2016). 
Próximo ao OAA existem algumas escolas básicas da rede pública de educação. Em entrevista a um dos professores de Geografia de uma dessas escolas, percebeu-se que apesar da proximidade com o OAA, o professor nunca visitou ou levou os seus estudantes para as palestras. Segundo o professor, apesar da proximidade, existem dificuldades com relação ao comportamento dos estudantes e associação dos assuntos da sala de aula com as aulas de Astronomia do OAA.

Assim, evidencia-se que os professores de Geografia que até mesmo ensinam próximos do espaço não-formal, desconhecem o que é trabalhado no OAA, enxergandoo apenas como construtor do ensino de Astronomia, desconhecendo que dentro do Observatório existe um Museu com inúmeras possibilidades de ensino de Geografia. Fica visível que os espaços não-formais ainda não são percebidos como uma possibilidade para o ensino de Geografia, visto que os professores que atuam nas proximidades não conseguem vislumbrar tal espaço como uma alternativa.

\section{CONCLUSÃO}

Com os questionários, entrevistas e observações, foi possível analisar como os professores de Geografia utilizam os espaços não-formais de ensino, em especial o Observatório Astronômico Antares de Feira de Santana - BA. Verificou-se que todos os professores de Geografia consideram importante no discurso o espaço não-formal de ensino, entretanto na prática, ainda grande parte está presa ao ambiente escolar, desconhecem as potencialidades dos espaços não-formais de ensino e suas colaborações para a Geografia.

Verificou-se que alguns professores Geografia utilizam os espaços não-formais de ensino tanto institucionalizados, quanto não-institucionalizados, para aulas expositivas e dialogadas, tentando fazer os alunos articularem os conteúdos com o que é observado no referido espaço. Geralmente, ao retornar para a sala de aula, os professores aplicam questionários, relatórios, portfólios, entre outros, para avaliar a aprendizagem.

Observa-se que existe um anseio comum entre os professores de Geografia, que a visita a um espaço não-formal para o ensino facilite a mediação em sala de aula. $\mathrm{O}$ 
espaço não-formal acaba colaborando com os assuntos de um espaço formal, cooperando para a construção do conhecimento, de conceitos de maior "complexidade", favorecendo o processo de ensino de Geografia na escola básica.

Em contrapartida, apesar das inúmeras carências de materiais didáticos e laboratórios relatadas pelos professores de Geografia na escola básica, averiguou-se que são poucos professores de Geografia que utilizam espaços não-formais de ensino, sendo que esses espaços podem suprir carências de materiais de ensino. Logo, verifica-se que muitas vezes o ensino de Geografia é apenas visto como produto dos espaços formais de educação, tornando o ensino restrito as salas de aula, levando o aluno imaginar que a Geografia só existe ali, ou não associar o que foi visto com a realidade.

Nessa perspectiva, a Geografia passa a não ser vista em toda parte, o mundo torna-se abstrato dentro de uma sala quadrada de ensino tradicional, o quadro branco tenta as vezes representar o mundo, mas na maioria das vezes, o mundo representado só é interpretado pelo próprio professor que somente valoriza a educação formal. A realidade não-formal, de lá de fora, tenta ser reproduzida formalmente ali dentro e muitas vezes, por falta de materiais e estrutura, não se tem bons resultados.

Conclui-se que é preciso valorizar os espaços não-formais para a construção do ensino de Geografia, pois além de suprirem a carência de materiais nas escolas, também potencializam a aprendizagem e trazem ainda mais sentido para o mundo e a realidade em volta dos alunos.

\section{REFERÊNCIAS}

CASTROGIOVANNI, A.C.; SOLER, J.M. Representando conheço o mundo: conhecer provisoriamente o mundo para a compreensão da vida incompreensiva. In: Conferência Internacional sobre os Sete Saberes necessários à Educação do Presente, 2010, Fortaleza: Anais da Conferência Internacional sobre os Sete Saberes necessários à Educação do Presente, 2010. v. 1.

GOHN, M. G. M. Educação não-formal e cultura Política: impactos sobre o associativismo no terceiro setor. 4. ed. São Paulo: Cortez, 2008.

JACOBUCCI, D. F. C. Contribuições dos Espaços Não-formais de Educação para a Formação da Cultura Científica. Uberlândia: Em Extensão, v. 7, p. 55-66, 2008.

MARTINS, H.H.T.S. Metodologia qualitativa de pesquisa. São Paulo: Educação e Pesquisa, v.30, n.2, p. 289-300, maio/ago. 2004. 
NASCIMENTO, F.N.; SGARBI, A.D.; ROLDI, K. A Utilização de espaços educativos não-formais na construção de conhecimentos - Uma experiência com alunos do ensino fundamental. Revista da SBEnBIO - v. 7, p. 2130-2139, 2014.

PAZ, W.C.; ANDRADE JR, A.R.; GUIMARÃES, C.J.; BASTIANI, A.C. O papel da educação não-formal e suas contribuições na formação cultural do cidadão. Revista Conexão UEPG, v. 7, p. 184-193, 2011.

PINTO, L.T.; FIGUEIREDO, V.A. O ensino de Ciências e os espaços não-formais de ensino. Um estudo sobre o ensino de Ciências no município de Duque de Caxias/RJ. In: II Simpósio Nacional de ensino de Ciência e Tecnologia, Ponta Grossa; PR: Anais, 2010 .

QUEIROZ, R.M.; TEIXEIRA, H.B.; VELOSO, A.S.; TERÁN, A. F.; QUEIROZ, A. G. A caracterização dos espaços não-formais de educação científica para o ensino de ciências. Manaus; AM: UEA, 2011.

ROMANZINI, J.; BATISTA, I. L. Os planetários como ambientes não-formais para o ensino de ciências. In: VII Enpec, Florianópolis, Anais, 2009.

SANTANA, V.R.; JÚNIOR, W. B. S. Estágio Supervisionado no Ensino de Geografia em Espaços não-formais. Natal-RN: ENALIC, 2014. 